\title{
Inheritance of the main quantitative traits in sweet sorghum hybrids $F_{1}$
}

\author{
Natalia Kovtunova ${ }^{1, *}$, Vladimir Kovtunov ${ }^{1}$, Aleksey Popov ${ }^{1}$, Aleksandr Volodin $^{2}$, Elena \\ Shishova ${ }^{1}$, Aleksandr Romanyukin ${ }^{1}$ \\ ${ }^{1}$ Federal State Budget Scientific Institution “Agricultural Research Center "Donskoy" (ARC \\ "Donskoy"), 3, Nauchny Gorodok, 347740, Rostov region, Zernograd, Russia, \\ ${ }^{2}$ Federal State Budget Scientific Institution "North-Caucasian Federal Research Agricultural Center" \\ (NCFRAC), 49, Nikonov Str., 356241, Stavropol region, Shpakovsky district, Mikhaylovsk, Russia
}

\begin{abstract}
Sweet sorghum hybrids $F_{1}$ in productivity can surpass the parental forms on $50-60 \%$. Thus the breeding process is aimed to develop first generation hybrids with a strong potential of productivity and quality of green mass and silage. The purpose of the work is to study heritability and heterosis of the quantitative traits of sweet sorghum hybrids $F_{1}$ obtained on a sterile basis. The study was conducted in 2013-2015 on the lines with cytoplasmic male sterility ('A-63', 'Knyazhna', 'APV-1115), the varieties ('Listvenit', 'Severnoe 44', 'Zernogradskoe 454', 'Stavropolskoe 36', 'Galiya' and 'Larets') and the hybrids. The inheritance of green mass productivity and absolutely dry matter, the length of a vegetation period, plant height and leaf formation (foliage), protein content in dry matter of the hybrids occurred according to the type of dominance and overdominance. It has been determined that while choosing the parental forms for hybridization it's essential to select the forms with differences in the vegetation period of 4-6 days to avoid the dominance of late maturity. The height pollinator increase results in the hybrid height increase and large heterosis. It's necessary to select the parental forms with maximum foliage to improve leaf formation in the hybrids.
\end{abstract}

\section{Introduction}

The primary purpose of all the breeders of any agricultural crop is to increase its productivity. There are a lot of grown varieties with large productivity of grain and green mass. Therefore, the further productivity increase is connected with development of heterosis hybrid forms. That's why the nowadays sweet sorghum breeding is aimed to develop first generation hybrids on a sterile basis with a strong potential of productivity and quality of green mass and silage [1,2,3]. Many researchers studied heterosis revealing in sorghum green mass productivity. They made a conclusion, that some hybrids can surpass the parental forms on $50-60 \%[4,5]$. There is a higher degree of dominance in productivity in dry years and a lower degree in more humid years [6]. The reason of it is that the parental forms are less productive in dry years and the dominance of hybrids is higher [7].

*Corresponding author: n-beseda@mail.ru 
It's important to obtain a heterosis form with not only a single trait, but to collect in a genotype as many desirable traits as possible. In that case it's necessary to receive the information about parental forms, about correlation of the gene responsible for development and inheritance of the main quantitative traits [8].

The purpose of the work is to study inheritance and heterosis of the quantitative traits of sweet sorghum hybrids $F_{1}$ obtained on a sterile basis.

\section{Materials and methods}

The study was conducted in 2013-2015 on the lines with cytoplasmic male sterility (CMSlines), varieties and hybrids developed in the Federal State Budget Scientific Institution "Agricultural Research Center "Donskoy" (ARC "Donskoy") and in the Federal State Budget Scientific Institution "North-Caucasian Federal Research Agricultural Center" (NCFRAC). The soil of the experimental plot (Zernograd, the Rostov region, Russia) is represented by carbonate, heavy loam black earth (chernozem obyknovenny) with 3.2-3.4\% of humus content in the plowing layer.

Agroclimatic conditions significantly varied through the years of study. During the sorghum vegetation period (May-September) there were $181 \mathrm{~mm}$ of precipitation in 2013, $134 \mathrm{~mm}$ in 2014 and $181 \mathrm{~mm}$ in 2015. According to the indexes of the hydrothermal coefficient the years of 2013-2014 were of average drought (HTC of 0.70 and 0.61). In 2015 the vegetation period was more humid (HTC of 0.80 ).

The objects of the study were 7 sweet sorghum hybrids $F_{1}$ obtained on a sterile basis, i.e. 'Zersil' ('APV-1115'x'Severnoe 44'), 'Silosnoe 88' ('A-63'x'Stavropolskoe 36'), 'Elisey' ('A-63'x'Listvenit'), 'Start' ('A-63'x'Zernogradskoe 454'), 'Alga' ('Knyazhna’x'Galiya'), 'Kalaus’ ('Knyazhna’x'Larets'), 'Dubler' ('APV1115'x'Zernogradskoe 454') (table 1).

Table 1. Characteristics of sweet sorghum hybrids.

\begin{tabular}{|c|c|c|c|c|c|c|}
\hline \multirow[b]{2}{*}{ Hybrid } & \multirow{2}{*}{$\begin{array}{c}\text { 'Sprouting- } \\
\text { total } \\
\text { maturity' } \\
\text { period. } \\
\text { days }\end{array}$} & \multirow{2}{*}{$\begin{array}{c}\text { Plant } \\
\text { height } \\
\text { during } \\
\text { ripening. } \\
\text { cm }\end{array}$} & \multirow[b]{2}{*}{$\begin{array}{c}\text { Leaf } \\
\text { formation. } \\
\%\end{array}$} & \multirow{2}{*}{$\begin{array}{c}\text { Protein } \\
\text { content } \\
\text { in dry } \\
\text { matter } \\
\text { of green } \\
\text { mass. } \%\end{array}$} & \multicolumn{2}{|c|}{ Productivity. t/ha } \\
\hline & & & & & $\begin{array}{c}\text { of green } \\
\text { mass }\end{array}$ & $\begin{array}{l}\text { of dry } \\
\text { matter }\end{array}$ \\
\hline $\begin{array}{l}\text { 'Zersil'. } \\
\text { standard }\end{array}$ & 105 & 199 & 16.2 & 9.9 & 59.3 & 18.4 \\
\hline 'Silosnoe 88' & 99 & 238 & 12.5 & 7.6 & 60.0 & 16.8 \\
\hline 'Elisey' & 111 & 199 & 22.0 & 10.1 & 70.3 & 20.3 \\
\hline 'Start' & 105 & 197 & 18.6 & 10.0 & 71.0 & 20.9 \\
\hline 'Alga' & 109 & 266 & 11.5 & 7.7 & 73.5 & 19.7 \\
\hline 'Kalaus' & 126 & 287 & 15.9 & 7.8 & 84.2 & 20.9 \\
\hline 'Dubler' & 104 & 201 & 14.6 & 9.6 & 66.9 & 18.9 \\
\hline Average & 108 & 227 & 15.9 & 9.0 & 69.3 & 19.4 \\
\hline
\end{tabular}

As parental forms there were used three CMS-lines ('A-63', 'Knyazhna', 'APV-1115), six highly productive varieties developed in the ARC "Donskoy" ('Listvenit', 'Severnoe 44', 'Zernogradskoe 454') and in the SRIA ('Stavropolskoe 36', 'Galiya' and 'Larets'). The objects of the study were the main economic valuable traits of sweet sorghum that significantly influence on productivity and quality of green mass for silage: a length of vegetation period, plant height, leaf formation (foliage), protein content in dry matter.

The sowing was carried out in optimal time (May, 3-10). The sowing rate was 200000 of germinating seeds per a hectare. The square of the plot was $25 \mathrm{~m}^{2}$ in 4 sequences, the 
plots' locations were randomized. The sweet sorghum was harvested for green mass in the period of 'milk-waxy ripeness'. The content of nutrients was conducted by the conventional method. The statistical analysis of the received data was done according to the methodology using the program Statistica 10.

\section{Results}

According to a vegetation period there were various types of inheritance: from hybrid depression ( $h p=-1.29)$ to overdominance $(h p=25.0)$ (table 2).

Table 2. Heterosis true $\left(\mathrm{H}_{\text {true }}\right)$ and dominance degree (hp) of quantitative traits of sweet sorghum hybrids.

\begin{tabular}{|c|c|c|c|c|c|c|c|c|c|c|c|c|}
\hline \multirow[t]{2}{*}{ Hybrid } & \multicolumn{2}{|c|}{$\begin{array}{c}\text { 'Sprouting } \\
\text {-total } \\
\text { maturity' } \\
\text { period } \\
\end{array}$} & \multicolumn{2}{|c|}{$\begin{array}{l}\text { Plant } \\
\text { height }\end{array}$} & \multicolumn{2}{|c|}{$\begin{array}{c}\text { Leaf } \\
\text { formation }\end{array}$} & \multicolumn{2}{|c|}{$\begin{array}{l}\text { Protein } \\
\text { content }\end{array}$} & \multicolumn{2}{|c|}{$\begin{array}{l}\text { Productivi } \\
\text { ty of green } \\
\text { mass }\end{array}$} & \multicolumn{2}{|c|}{$\begin{array}{l}\text { Productivi } \\
\text { ty of dry } \\
\text { matter }\end{array}$} \\
\hline & $\mathbf{H}_{\text {tru }}$ & hp & $\mathbf{H}_{\text {tru }}$ & hp & $\mathbf{H}_{\text {tru }}$ & hp & $\mathbf{H}_{\text {tru }}$ & hp & $\mathbf{H}_{\text {tru }}$ & hp & $\mathbf{H}_{\text {tru }}$ & hp \\
\hline 'Zersil' & -4.5 & 0.4 & 8.1 & 1.9 & 7.3 & 1.6 & 22.2 & 37.0 & 28.9 & 1.9 & 16.5 & 1.5 \\
\hline $\begin{array}{c}\text { 'Silosnoe } \\
88 '\end{array}$ & -7.5 & -1.3 & 7.7 & 1.4 & $\begin{array}{c}- \\
33.2\end{array}$ & -0.3 & $\begin{array}{c}- \\
10.6\end{array}$ & -0.1 & 26.8 & 1.9 & 28.2 & 2.0 \\
\hline 'Elisey' & 3.7 & 2.3 & 3.1 & 1.2 & 17.6 & 3.4 & 18.8 & 3.1 & 52.8 & 2.8 & 31.0 & 1.9 \\
\hline 'Start' & -1.9 & 0.6 & 5.3 & 1.4 & -0.5 & 0.9 & 17.6 & 3.7 & 55.7 & 2.9 & 54.4 & 2.7 \\
\hline 'Alga' & 12.4 & 25.0 & 17.2 & 2.2 & -8.7 & -6.3 & $\begin{array}{c}- \\
18.9\end{array}$ & -0.8 & 47.9 & 2.5 & 44.8 & 2.5 \\
\hline 'Kalaus' & 15.6 & 3.8 & 21.1 & 2.4 & 12.8 & 3.0 & $\begin{array}{c}- \\
17.9\end{array}$ & -0.1 & 51.4 & 2.6 & 27.4 & 1.8 \\
\hline 'Dubler' & 6.1 & 4.0 & 7.5 & 1.8 & 16.8 & 5.2 & 7.9 & 2.6 & 46.7 & 2.4 & 37.0 & 2.2 \\
\hline $\begin{array}{c}\text { Average } \\
\text { of CMS- } \\
\text { line 'A- } \\
63 \text { ' }\end{array}$ & -1.9 & 0.4 & 5.5 & 1.3 & -5.3 & 0.7 & -8.6 & 2.0 & 44.9 & 2.5 & 36.8 & 2.2 \\
\hline $\begin{array}{l}\text { Average } \\
\text { of CMS- } \\
\text { line } \\
\text { 'Knyazhn } \\
\text { a' }\end{array}$ & 14.6 & 6.4 & 19.2 & 2.3 & 2.6 & 1.7 & 18.4 & -0.4 & 49.8 & 2.6 & 35.3 & 2.1 \\
\hline $\begin{array}{c}\text { Average } \\
\text { of CMS- } \\
\text { line } \\
\text { 'APV- } \\
1115 \text { ' }\end{array}$ & 0.5 & 1.1 & 7.8 & 1.8 & 11.6 & 2.4 & 14.7 & 6.0 & 37.8 & 2.1 & 26.0 & 1.8 \\
\hline
\end{tabular}

The hybrids developed from the CMS-line 'Knyazhna' possessed the largest heterosis in the length of a vegetation period (30.95 and $14.63 \%$ respectively). The hybrids 'Silosne', 'Start' and 'Zersil' possessed a hybrid depression which is of great interest in the breeding on early maturity. These hybrids ripened on 3-5 days earlier than their parental forms, their true heterosis was $-7.5 \ldots-1.9 \%$.

Plant height, length of a vegetation period, inherited with a high degree of heterosis can be improved in hybrids. The hybrids of the first generation, depending on the selection of parental forms, can become more fast-maturing or occupy an intermediate position between them or lag behind them [9]. In our study inheritance of length of a vegetation period was of a dominant character. While selecting the parental forms for hybridization it's necessary to choose the forms of the vegetation period with 4-6 days of difference to avoid the 
dominance of late-maturity. In this case, the hybrid $F_{1}$ will already have on 1-5 days more early-maturing hybrids than their parental forms.

Plant height of the hybrids on the 30-th day of growing (intensity of initial growth) was 43-54 cm. In general, all hybrids possess overdominance ( $\mathrm{hp}=1.2-4.3)$. Plant height in the period of full ripeness was from $197 \mathrm{~cm}$ ('Start') to $287 \mathrm{~cm}$ ('Klaus'). All combinations possess overdominance in this trait $(\mathrm{hp}=1.2-2.4)$ with the indexes of true heterosis from $3.1 \%$ ('Elisey') to $21.1 \%$ ('Klaus').

The manifestation of the trait in the hybrids depends on the genotypes of the initial parental forms $[10,11]$. The analysis of plant height correlation between hybrids and parental forms showed that the father form had the largest effect on plant height $(r=0.98$, $\mathrm{t}_{\text {fact. }}$ 97.66 $>\mathrm{t}_{\text {theor. }}$ 2.57, where $\mathrm{r}-\mathrm{a}$ coefficient of correlation, $\mathrm{t}_{\text {fact. }}-$ obtained criterion of the correlation coefficient significance, $t_{\text {theor }}$ - theoretical index of criterion of the correlation coefficient significance) (table 3 ).

Table 3. Correlation of hybrids and parental forms in the main economic-valuable traits of sweet sorghum.

\begin{tabular}{|c|c|c|c|c|c|c|}
\hline Trait & $\mathbf{r}_{\mathbf{F 1} / \mathbf{m . f}}{ }^{*}$ & $\mathbf{S}_{\mathbf{r}}$ & $\mathbf{t}_{\text {fact. }}$ & $\mathbf{r ~ F 1 / f . f . ~}^{*}$ & $\mathbf{S}_{\mathbf{r}}$ & $\mathbf{t}_{\text {fact. }}$ \\
\hline $\begin{array}{c}\text { 'Sprouting-total } \\
\text { maturity' period }\end{array}$ & -0.25 & 0.19 & 1.3 & 0.48 & 0.15 & 3.17 \\
\hline Plant height & 0.73 & 0.09 & 7.93 & 0.98 & 0.01 & 97.66 \\
\hline Leaf formation & 0.89 & 0.04 & 20.8 & 0.82 & 0.07 & 12.5 \\
\hline $\begin{array}{c}\text { Protein content in } \\
\text { green mass }\end{array}$ & -0.72 & 0.10 & 7.4 & 0.50 & 0.15 & 3.36 \\
\hline $\begin{array}{c}\text { Productivity of } \\
\text { green mass }\end{array}$ & 0.53 & 0.14 & 3.69 & 0.78 & 0.08 & 10.06 \\
\hline $\begin{array}{c}\text { Productivity of dry } \\
\text { matter }\end{array}$ & 0.05 & 0.20 & 0.25 & 0.44 & 0.16 & 2.74 \\
\hline
\end{tabular}

Note: $\mathrm{r}_{\mathrm{F} 1 / \mathrm{m} . \mathrm{f} \text {. }}$ - correlation of the values of $\mathrm{F}_{1}$ hybrid and mother form,

$r_{\mathrm{F} 1 / \text { f.f.. }}-$ correlation of the values of $\mathrm{F}_{1}$ hybrid and father form,

$\mathrm{s}_{\mathrm{r}}$ - mistake of correlation coefficient

$\mathrm{t}_{\text {fact. }}$ - obtained criterion of the correlation coefficient significance

Value $t_{\text {theor. }}$ on $5 \%$ level of significance 2.57 (degree of freedom $(n-2)=5$ )

Critical value of the correlation coefficient on $5 \%$ level of significance 0.754 (degree of freedom $(\mathrm{n}-2)=5)$.

The increase of pollinator's height results in increase of hybrid's height. While developing the hybrids 'Alga' and 'Kalaus' there were used the highest initial forms-lines 'Knyazhna' and the pollinator 'Galiya' $(227 \mathrm{~cm})$, 'Larets' $(237 \mathrm{~cm})$ that allowed obtaining the maximum heterosis effect $(7.2-21.1 \%)$.

Leaf formation. Leaf width of the sweet sorghum hybrids $\mathrm{F}_{1}$ tends to reduce while leaf length and leaf formation (foliage) tends to increse $[12,13]$. Leaf formation (foliage) is closely connected with green mass productivity $[14,15]$. The largest leaf formation was noticed in the hybrid 'Elisey' $(22.0 \%)$; it exceeded the best parent on $17.6 \%$. In our study inheritance of leaf formation was of a dominant character. However, there was a significant dominance over parental forms in the hybrids which demonstrated heterosis in length of a vegetation period as well, i.e. in more late-maturing hybrids.

Both the mother $\left(r=0.89\right.$ when $t_{\text {fact. }}$ 20.8) and father $\left(r=0.82\right.$ when $t_{\text {fact. }}$ 12.5) forms had an effect on the manifestation of this trait in the hybrid.

The study of inheritance of protein content in green mass of sweet sorghum has determined that it's necessary to use the samples with the largest values to produce the forms with high content of protein as initial material. Protein content in the hybrids ranged from $7.6 \%$ ('Silosnoe 88 ') to $10.1 \%$ ('Elisey'). The four hybrids ('Elisey', 'Start', 'Zersil', 
'Dubler') exceeded the best parent with the values $H_{\text {true }}=7.9-22.2 \%$. They also demonstrated overdominance of the large values $(\mathrm{hp}=2.6-37.0)$.

The mother line had the greatest effect on the manifestation of the hybrid trait $(\mathrm{r}=-0.72$ when $t_{\text {fact. }}$ 7.4). Large protein content in green mass of the CMS-line decreased this index in the hybrid. The maximum manifestation of heterosis $\left(\mathrm{H}_{\text {true }}=14.7 \%\right)$ was seen in the hybrids developed with the use of the CMS-line 'APV-1115', which was characterized by the least protein content in green mass $(8.0 \%)$ compared with other lines.

Productivity of green mass (chop) and dry matter of the hybrids ranged from 59.3-84.2 $\mathrm{t} /$ ha to $16.8-20.9 \mathrm{t} / \mathrm{ha}$ respectively. The researchers found out that the first generation hybrids could exceed the parental forms on $50-70 \%$ and more $[16,17]$. According to these indexes absolutely all hybrids possessed high true heterosis. The hybrid 'Klaus' demonstrated the largest value of productivity, exceeded the best parental form on $28.6 \mathrm{t} / \mathrm{ha}$ and $5.1 \mathrm{t} / \mathrm{ha}$, its true heterosis was $51.4 \%$ and $27.4 \%$ respectively. The hybrid 'Silosnoe' demonstrated the least value of heterosis in productivity of green mass $(26.8 \%)$, the hybrid 'Zersil' showed the least value of absolutely dry matter (16.5\%).

The inheritance of the traits was based on the type of overdominance. The overdominance degree was 1.9-2.9 in productivity of green mas and 1.5-2.7 in productivity of absolutely dry matter. Simultaneous heterosis according to all traits is a rather rare phenomenon. In the current study heterosis in productivity of green mass was caused by a simultaneous increase of plant height, stem diameter and plant foliage. This has been confirmed by the study of G. M. R. Lombardi et al [18].

Correlation coefficients have indicated that the main part in the formation of green mass productivity was played by the pollinator $\left(r=0.78\right.$ at $\left.t_{\text {fact }} .10 .06\right)$, that is, the form with the highest productivity. This has been consistent with the study of M. Riyazaddin et al [19].

\section{Results}

1. In our study inheritance of length of a vegetation period was of a dominant character. While selecting the parental forms for hybridization it's necessary to choose the forms of the vegetation period with 4-6 days of difference to avoid the dominance of latematurity. In this case, the hybrid $F_{1}$ will already have on 1-5 days more early-maturing hybrids than their parental forms.

2. Almost all hybrids possessed overdominance in plant height. The increase of pollinator's height results in increase of hybrid's height.

3. Inheritance of leaf formation is of a dominant character. Both the mother and father forms have an equal effect on the manifestation of this trait in the hybrid. It's essential to select parental forms with a maximum foliage to increase the index.

4. According to the protein content there have been identified various types of inheritance. However, high protein content in green mass of the CMS-line results in a decrease in this indicator in the hybrid.

5. According to these indexes absolutely all hybrids possessed high true heterosis. Correlation coefficients indicate that the main part in the formation of green mass productivity was played by the pollinator.

\section{References}

1. M.A. Sayed, R.E. Elsaid Mahdy, Egypt. J. Plant Breed 20(3), 561 - 580 (2016) DOI: $10.12816 / 0031415$

2. N.A. Kovtunova, A.B. Volodin, V.V. Kovtunov, Grain Economy of Russia 1, 11-17 (2017) 
3. D. Bunphan, P. Jaisil, J. Sanitchon, J.E. Knoll. Crop Science 55(1), 178 (2015) DOI: 10.2135/cropsci2014.05.0363

4. R. Chittapur, B.D. Biradar, Indian J. Agric. Res. 49(5), 468-471 (2015)

5. R.A. Sami, Journal of Biology, Agriculture and Healthcare 3(17), 49-51 (2013)

6. D. Bello, A.M. Kadams, S.Y. Simon, D.S. Mashi, American-Eurasian J. Agric. Environ. Sci. 2(3), 297-302 (2007)

7. M. Ahmed, Fayyaz-ul-H., Q. Ummara, M.A. Aslam, African Journal of Agricultural Research 6(3), 594-607 (2011)

8. N.A. Kovtunova, V.V. Kovtunov, E.A. Shishova, The newsletter of the Russian Agricultural Science 3, 39-41 (2016)

9. J. Ringo, A. Onkware, M. Mgonja, S. Deshpande, A. Rathore, E. Mneney, S. Gudu, AJCS 9(1), 9-13 (2015)

10. R. Justin, B. Were, M. Mgonja, D. Santosh, R. Abhishek, M. Emmarold, O. Agustino, G. Samuel, African Journal of Agricultural Research 10(19), 2048-2060 (2015) doi.org/10.5897/AJAR2014.8519

11. T.T. Mindaye, E.S. Mace, I.D. Godwin, D.R. Jordan, Crop. Journal 4(6), 479-489 (2016) doi.org/10.1016/j.cj.2016.06.020

12. S.K. Singh, K. Pal, B. Kumar, C. Singh, Biochemical and Cellular Archives 17(1), 7996 (2017)

13. S.I. Kapustin, A.B. Volodin, A.S. Kapustin, Ukrainian Journal of Ecology 8(3), 273281 (2018)

14. M.A.M. Rachmadi, The 3rd International Conference on Biological Science 2, 318325 (2015)

15. A.E. Romanyukin, E.A. Shishova, N.A. Kovtunova, G.M. Ermolina, Agricultural Newsletter of the Urals 7(149), 46-50 (2016)

16. R. Chittapur, B.D. Biradar, Indian Journal of Agricultural Research 49(5), 468-471 (2015) doi.org/10.18805/ijare.v49i5.5814

17. R.A. Sami, Journal of Biology, Agriculture and Healthcare 3(17), 49-51 (2013)

18. G.M.R. Lombardi, P.C.A. Navegantes, C.H. Pereira, J.M.O. Fonseca et. al. Pesq. agropec. bras. 53(5) (2018) doi.org/10.1590/s0100-204x2018000500008

19. M. Riyazaddin, A.K. Are, R. Bhavanasi, R.S. Munghate, P.B.K. Kishor, H.C. Sharma. Frontiers in Plant Science 6(945), 1-17 (2015) doi.org/10.3389/fpls.2015.00945 